\title{
REVIEW
}

Open Access

\section{Mesenchymal stromal/stem cells and their exosomes for restoration of spermatogenesis in non-obstructive azoospermia: a systemic review}

Rano Zhankina ${ }^{1 \dagger}$, Neda Baghban $^{2 \dagger}$, Manarbek Askarov ${ }^{1}$, Dana Saipiyeva ${ }^{1}$, Almaz Ibragimov ${ }^{1}$, Bakhyt Kadirova ${ }^{1}$, Arezoo Khoradmehr ${ }^{2}$, Iraj Nabipour ${ }^{2}$, Reza Shirazi ${ }^{3^{*}}$, Ulanbek Zhanbyrbekuly ${ }^{1 *}$ and Amin Tamadon ${ }^{2^{*}}$ (D)

\begin{abstract}
Stem cells have been introduced as new promising therapeutic agents in treatment of degenerative diseases because of having high differentiation potential while maintaining the ability to self-replicate and retaining features of their source cells. Among different type of cell therapies, mesenchymal stromal/stem cell (MSC) therapy is being increasingly developed as a new way to treat structural defects that need to be repaired and regenerated. Nonobstructive azoospermia (NOA) is a reproductive disease in men that causes infertility in $10 \%$ of infertile men. Based on in vitro studies, MSCs from different tissue sources have been differentiated into germ cells or gamete progenitor cells by simple methods in both male and female. On the other hand, the therapeutic effects of MSCs have been evaluated for the treatment of NOA animal models created by chemical or surgical compounds. The results of these studies confirmed successful allotransplantation or xenotransplantation of MSCs in the seminiferous tubules. As well, it has been reported that exosomes secreted by MSCs are able to induce the process of spermatogenesis in the testes of infertile animal models. Despite numerous advances in the treatment of reproductive diseases in men and women with the help of MSCs or their exosomes, no clinical trial has been terminated on the treatment of NOA. This systematic review attempts to investigate the possibility of MSC therapy for NOA in men.
\end{abstract}

Keywords: Non-obstructive azoospermia, Infertility, Mesenchymal stromal/stem cell, In vitro study, Animal model, Clinical trial

\footnotetext{
*Correspondence: reza.shirazi@unsw.edu.au; ulanbek.amu@gmail.com; amintamaddon@yahoo.com

${ }^{+}$Rano Zhankina and Neda Baghban are co-first authors

${ }^{3}$ Department of Anatomy, School of Medical Sciences, Medicine, UNSW Sydney, PO Box 2052, Sydney, Australia

'Department of Urology and Andrology, Astana Medical University,

Nur-Sultan, Kazakhstan 010000

${ }^{2}$ The Persian Gulf Marine Biotechnology Research Center, The Persian Gulf

Biomedical Sciences Research Institute, Bushehr University of Medical

Sciences, Bushehr 7514633196, Iran
} 


\section{Introduction}

In the current decade, the emerging field of stem cell therapy has quickly become a new era of regenerative medicine. The diverse potential of stem cells is a focus of research of many scientists in molecular biology, genetic engineering, and even general medicine for developing new approaches in the treatment of a number of diseases, which have always been a challenge for clinicians [1].

Stem cells are cells that are self-sustaining throughout the life of an organism and capable of differentiating into cells of various types. There are several types of stem cells found in human tissues. Among them, mesenchymal stromal/stem cells (MSCs) derived from various tissues including the bone marrow and adipose tissue have been considered to be the most promising material in terms of their application for cell therapy. The MSCs are popular among scientists and clinicians due to their multilinear differentiation potential, low immunogenicity and active participation in tissue repair, and regeneration after migration to damaged sites. In general, MSCs have advantages over other types of stem cells for clinical use in cell-based therapies. These advantages include availability, easy to isolate and expand, multilineal differentiation, immunosuppressive, and both of the autograft and allograft are possible, free from ethical issues, and limited replicative lifespan [2].

According to World Health Organization (WHO) criteria, the marriage is considered infertile, if no pregnancy occurs within 12 months of unprotected sex [3]. This pathology is an important medico-social issue with up to one in six of married couples failing to conceive naturally [4]. Among them, $20-30 \%$ of infertility is related solely to men [5]. Infertility cases are linked to the diminished quantity or quality of ejaculate, which may be due to impaired spermatogenesis, slow maturation of spermatozoa in the epididymis, or incomplete patency of the vas deferens. The main causes of male infertility are genetic disorders, urogenital infections, hypogonadism, cryptorchidism, varicocele, ejaculatory disorders, general and systemic diseases, and immunological factors [6]. Despite its multifactorial nature, male infertility has not been fully understood and about half of cases are considered idiopathic or unexplained [7]. Investigation of male fertility usually starts with history, physical examination, and spermogram.

Azoospermia is classified as obstructive and nonobstructive (NOA). In most patients with NOA, it is possible to distinguish clinically by diagnostic workup including history, hormone levels, and physical examination. These indicators allow to confidently determine the type of azoospermia. This is important, since obstructive azoospermia is more favorable due to preservation spermatogenesis. However, the NOA accounts for about $10 \%$ of infertility cases and manifests as the absence of spermatozoa in ejaculates due to spermatogenic deficiency. In the overwhelming majority of cases, azoospermia is associated with a number of irreversible disorders of the testicles, which lead to inhibition of spermatogenesis. Such disorders are most often linked to endocrine, genetic, and inflammatory diseases [8]. In addition, NOA can be idiopathic [9]. Palpation and measurement usually reveal small and flabby testicles typical for non-obstructive azoospermia. In all patients with azoospermia, the levels of follicle stimulating hormone (FSH), luteinizing hormone $(\mathrm{LH})$, prolactin, total testosterone, estradiol, and inhibin $\mathrm{B}$ should be measured [10]. In most patients with NOA, FSH is increased $(>7.6 \mathrm{IU} / \mathrm{mL})$ and $\mathrm{LH}$ is elevated or close to normal [11]. Hypogonadism is defined by low total testosterone levels $(<300 \mathrm{ng} / \mathrm{dL})$ and occurs in the majority of patients with NOA, usually reflecting Leydig cell deficiency [12]. Obesity can be associated with low total testosterone levels, thereby serum estradiol levels increase due to elevated aromatization of androgens in peripheral tissues [13]. Low testosterone in obese patients may also reflect adaptation to altered sex hormone-binding globulin (SHBG) rather than true testosterone deficiency [14].

Proper counseling and management of patients with NOA presents a challenge for andrologists, urologists, and reproductive medicine specialists. Despite this, advances in molecular biology, hormone replacement therapy, and microsurgical sperm retrieval, together with modern techniques of in vitro fertilization (IVF), give hope for natural paternity. By the way application of MSC for treatment of NOA needs more clarification which this systemic review attempts to do it.

\section{Methods \\ Focused question}

This systematic review was done to answer this question: "Could MSCs be applied in treatment of NOA in human?"

\section{Search and study selection}

Key words and subject terms included ("MSC" AND "azoospermia") OR ("MSC" AND "azoospermia" AND "therapy") OR ("MSC" AND "germ cell") OR ("MSC" AND "infertiltiy") OR ("MSC" AND "reproductive"). The search strategy was applied to Google Scholar and ClinicalTrials.gov, being focused on the in vitro or in vivo studies and clinical trials, respectively. English language publications were considered. The reviews, abstracts without full manuscripts, the manuscripts about non-male reproductive system MSCs therapy, and stem cell sources other than MSCs were excluded. Data were collected from the full text of the articles as follows: (i) 
the source of MSCs, (ii) type of the study (in vitro, in vivo, or clinical trials), and (iii) the obtained results.

\section{Treatment of NOA}

The NOA has been considered to be a condition not responding to drug therapy [15]. Patients with NOA are unable to have children of their own and have options of either adoption or using donated sperm [16]. Despite the marked changes in spermatogenesis, these patients still have a chance to conceive. In such situations, the preservation of spermatogenesis may be focal in testicular tissues [17]. Due to irreversible nature of spermatogenesis damage in patients with NOA, testicular biopsy and assisted reproductive technologies are the only ways to obtain biological off-springs [18]. For men with NOA, testicular sperm extraction (TESE) with intracytoplasmic sperm injection (ICSI) remains the only choice to conceive [19]. However, TESE-ICSI has limited success in patients with NOA, as during the first TESE cycle, sperm is found about $50 \%$ of cases [20], and the subsequent probability of egg fertilization with ICSI is about $50 \%$ [21]. As a result, the successful fertilization probability with this technique is about $13.4 \%$ [22]. Therefore, considering this low success rate and due to their unlimited source and high differentiation potential, MSCs have been considered as a potential new therapeutic agent for the treatment of infertility.

\section{MSC-therapy of NOA}

The MSCs were first described by Alexander Friedenstein (1924-1998) [23]. He experimentally proved the existence of stromal stem cells in the bone marrow and in lymphoid organs [24]. This discovery confirmed that the bone marrow contains a distinct population of stem cells capable of forming clones of cells of connective and hematopoietic lines [24]. Approximately $30 \%$ of the bone marrow aspirate isolated by Friedenstein consisted of MSCs [24]. These cells showed plastic adhesion capacity and were able to support differentiation and growth of various hematopoietic cell lines [24].

The MSCs are multipotent human stromal/stem cells able to self-renew [25]. The general properties of MSCs include high proliferative potential and adhesion capacity, symmetric and asymmetric division, fibroblast-like morphology, easily induced differentiation, and the formation of colonies in a culture [25]. MSCs are able to differentiate into chondrocytes, fibroblasts, osteoblasts, adipocytes, and myoblasts [25]. The therapeutic effect of MSCs is based on their ability to secrete a number of signaling molecules, which simulate the functional activity of various targets in of the body [25]. The MSCs promote growth of hematopoietic progenitors by forming the specific microenvironment (niche) [26]. To date, the following markers have been detected on the surface of
MSC cells isolated from various tissues: CD105, CD106,

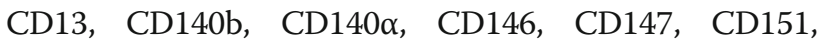
CD166, CD276, CD29, CD44, CD47, CD49, CD49E, CD54, CD56, CD59, CD73, CD81, CD9, CD90, CD90.1, CD98, HLA-I, Klf-4, NANOG, nestin, NG2, Oct-3, OCT-4, PDGF-R $\beta$, prolyl-4-hydroxylase, Sox-17, SSEA3 , STRO-1, and $\alpha$-SMA [27].

Besides MSCs, MSC-derived exosomes can mediate cell activity and paracrine actions through carriage of proteins, lipids miRNAs, and mRNAs into target cells [28, 29]. Moreover, exogenous exosomes regulate expression of protein or target gene resulting regulation of function of the recipient cell [30]. It has been reported that exosomes have ability to stimulate effects of stem cell-like proregenerative in damaged regions directly [31].

The bone marrow is one of the main sources of MSCs, and although its aspiration is the most traumatic way among the MSC isolation procedures, it is the most evaluated approach for cell therapy [32]. The MSC number, differentiation potential, and the viability of the bone marrow MSCs (BM-MSCs) decrease with age [33]. In this regard, the ongoing search for alternative sources of MSC is going on. MSCs derived from the adipose tissue (AT-MSCs) can be alternative solution for BM-MSCs due to their comparable differentiation and therapeutic potential [34]. The adipose tissue is not only a metabolic reservoir for storage and formation of high-energy substrates, but also participates in hormone metabolism [35]. More profound study of the adipose tissue structure was performed by Martin Rodbell (1925-1998) who used techniques of proteolytic cleavage, mechanical grinding, and differential centrifugation for isolating 2 fractions of the adipose tissue-mature adipocytes and, more compact, cellular substance, which he later called stromal-vascular fraction (SSF) [36]. The SSF is heterogeneous and includes MSCs, preadipocytes, endothelial cells, pericytes, T cells, and M2 macrophages, fibroblasts, and pre-adipocytes [37]. In 2001, Zuk et al. [38] noted that properties of so-called AT-MSCs are similar to BMMSCs. In an adult bone marrow, the ratio of MSCs to total cells is $1: 10,000-100,000$ [39], whereas in the adipose tissue, the ratio of MSCs to total cells is 1:30 [40]. AT-MSCs are easier and safer to obtain than BM-MSCs. The primary acquisition of AT-MSC is based on the manually procedure performed with the involvement of lipoaspirate fermentation technique [41]. The adipose tissue suitable for MSC isolation can be obtained either by skin flaps [42] or liposuction (LS) [43].

\section{AT-MSC collection approaches for treatment of NOA}

LS as a surgical intervention is preferable for aspirating adipose tissue suitable for isolation of MSC [44]. Considering complications and the little traumatic impact of LS, no long-term postoperative rehabilitation of patients 
Table 1 Differentiation of mesenchymal stromal/stem cells (MSC) into male germ cells in vitro

\begin{tabular}{|c|c|c|c|c|}
\hline MSC source & Source age & Species & Inducer & References \\
\hline Adipose tissue & Adult & Dog & BMP4 & {$[65]$} \\
\hline Adipose tissue & Adult & Dog & CD61 overexpression & {$[66]$} \\
\hline Adipose tissue & Adult & Goat & $\begin{array}{l}\text { BOULE overexpression } \\
\text { DAZL overexpression } \\
\text { STRA8 overexpression }\end{array}$ & {$[67]$} \\
\hline Adipose tissue & Adult & Human & Retinoic acid & {$[68]$} \\
\hline Adipose tissue & Adult & Mouse & $\begin{array}{l}\text { BMP4 } \\
\text { EGF } \\
\text { GDNF } \\
\text { LIF } \\
\text { Retinoic acid }\end{array}$ & {$[69]$} \\
\hline Adipose tissue & Adult & Mouse & $\begin{array}{l}\text { Sertoli cells co-culture } \\
\text { Retinoic acid } \\
\text { Testosterone }\end{array}$ & [70] \\
\hline Adipose tissue & Adult & Mouse & $\begin{array}{l}\text { Testicular cell conditioned medium } \\
\text { Retinoic acid }\end{array}$ & [71] \\
\hline Amniotic membrane & Fetal & Human & Retinoic acid & [72] \\
\hline Amniotic membrane & Fetal & Mouse & $\begin{array}{l}\text { BMP4 } \\
\text { Retinoic acid }\end{array}$ & [73] \\
\hline Bone marrow & Adult & Goat & $\begin{array}{l}\text { BMP4 } \\
\text { Retinoic acid }\end{array}$ & [74] \\
\hline Bone marrow & Adult & Human & $\begin{array}{l}\text { Retinoic acid } \\
\text { Sertoli cell-conditioned medium }\end{array}$ & [75] \\
\hline Bone marrow & Adult & Human & Retinoic acid & [76] \\
\hline Bone marrow & Adult & Mouse & BMP4 & {$[77,78]$} \\
\hline $\begin{array}{l}\text { Bone marrow } \\
\text { Adipose tissue }\end{array}$ & Adult & Mouse & $\begin{array}{l}\text { BMP4 } \\
\text { Retinoic acid }\end{array}$ & [79] \\
\hline Bone marrow & Adult & Mouse & $\begin{array}{l}\text { BMP4 } \\
\text { Retinoic acid }\end{array}$ & {$[80]$} \\
\hline Bone marrow & Adult & Mouse & Retinoic acid & {$[81-83]$} \\
\hline Bone marrow & Adult & Mouse & Sertoli cell-condition medium & {$[84]$} \\
\hline Bone marrow & Adult & Mouse & $\begin{array}{l}\text { Static magnetic field } \\
\text { BMP4 }\end{array}$ & {$[85]$} \\
\hline Bone marrow & Adult & Mouse & $\begin{array}{l}\text { Retinoic acid } \\
\text { Testicular cell co-culture }\end{array}$ & {$[86]$} \\
\hline Bone marrow & Adult & Rat & $\begin{array}{l}\text { bFGF } \\
\text { LIF } \\
\text { Retinoic acid }\end{array}$ & {$[87]$} \\
\hline Bone marrow & Adult & Rat & Retinoic acid & {$[88]$} \\
\hline Bone marrow & Adult & Rat & Sertoli cell co-culture & [89] \\
\hline Bone marrow & Adult & Sheep & Inorganic zinc (sulfate) & {$[90]$} \\
\hline Bone marrow & Adult & Sheep & $\begin{array}{l}\text { Inorganic zinc (sulfate) } \\
\text { Organic zinc (acetate) } \\
\text { Retinoic acid }\end{array}$ & [91] \\
\hline Bone marrow & Adult & Sheep & $\begin{array}{l}\text { Retinoic acid } \\
\text { TGF- } \beta 1\end{array}$ & [92] \\
\hline Bone marrow & Adult & Sheep & Retinoic acid & [93] \\
\hline Bone marrow & Adult & Sheep & $\begin{array}{l}\text { TGFb1 } \\
\text { BMP4 } \\
\text { BMP8b }\end{array}$ & [94] \\
\hline Bone marrow & Fetal & Human & $\begin{array}{l}\text { Retinoic acid } \\
\text { Testicular extracts }\end{array}$ & [95] \\
\hline Lung & Fetal & Human & Retinoic acid & [96] \\
\hline
\end{tabular}


Table 1 Differentiation of mesenchymal stromal/stem cells (MSC) into male germ cells in vitro (Continued)

\begin{tabular}{|c|c|c|c|c|}
\hline MSC source & Source age & Species & Inducer & References \\
\hline Umbilical cord & Fetal & Human & $\begin{array}{l}\text { BMP4 } \\
\text { Retinoic acid }\end{array}$ & {$[97,98]$} \\
\hline Umbilical cord & Fetal & Human & BMP4 & [99] \\
\hline Umbilical cord & Fetal & Human & pCD61-CAGG-TRIP-pur (oCD61) plasmid & {$[100]$} \\
\hline Umbilical cord & Fetal & Human & Testicular cell co-culture & {$[101]$} \\
\hline Wharton's jelly & Fetal & Human & $\begin{array}{l}\text { BMP4 } \\
\text { Testicular cell-conditioned medium } \\
\text { Placental cell-conditioned medium } \\
\text { Retinoic acid }\end{array}$ & {$[102]$} \\
\hline Wharton's jelly & Fetal & Human & $\begin{array}{l}\text { BMP4 } \\
\text { Placenta cell co-culture } \\
\text { Retinoic acid }\end{array}$ & [103] \\
\hline Wharton's jelly & Fetal & Human & $\begin{array}{l}\text { Retinoic acid } \\
\text { Testosterone } \\
\text { Testicular cell-conditioned medium }\end{array}$ & [104] \\
\hline Wharton's jelly & Fetal & Human & Retinoic acid & {$[105,106]$} \\
\hline Wharton's jelly & Fetal & Human & Sertoli cell co-culture & {$[107]$} \\
\hline
\end{tabular}

Abbreviations: $b F G F$ basic fibroblast growth factor, BMP bone morphogenetic protein, EGF epidermal growth factor, GDNF glial cell line-derived neurotrophic factor LIF leukemia inhibitory factor, TGFb1 transforming growth factor-beta 1

is required following this operation [45]. Currently, there are various techniques for LS implementation as new state-of-the-art equipment continues to emerge such as ultrasound or laser $[46,47]$. The most popular option though is classical tumescent LS, where fat tissue in the donor area of the patient's body is infiltrated with a mixture of sterile saline with low concentrations of local anesthetic and epinephrine [48]. The LS technique may have negative or positive effects on viability and quantity of MSC isolated from fat tissue [49, 50]. With classical LS, the negative pressure in the aspirator is reversely proportional to the number of isolated stem cells [51]. According

Table 2 Differentiation of mesenchymal stromal/stem cells (MSC) into female germ cells in vitro

\begin{tabular}{|c|c|c|c|c|}
\hline MSC source & Source age & Species & Inducer & References \\
\hline $\begin{array}{l}\text { Adipose tissue } \\
\text { Ovary } \\
\text { Skin }\end{array}$ & Adult & Pig & Follicular fluid & [108] \\
\hline $\begin{array}{l}\text { Amniotic membrane } \\
\text { Chorion } \\
\text { Umbilical cord }\end{array}$ & Fetal & Human & BMP4 & [109] \\
\hline Follicular fluid & Adult & Human & BMP15 & [110] \\
\hline Menstrual blood & Adult & Human & $\begin{array}{l}\text { Polylactic acid } \\
\text { Multi-wall carbon nanotubes }\end{array}$ & [111] \\
\hline Menstrual blood & Adult & Human & Follicular fluid & [112] \\
\hline Muscle & Fetal & Pig & Follicular fluid & [113] \\
\hline Ovary & Adult & Mouse & Oct4 overexpression & [114] \\
\hline Ovary & Fetal & Cow & $\begin{array}{l}\text { BMP4 } \\
\text { BMP2 } \\
\text { Follicular fluid }\end{array}$ & [115] \\
\hline Peritoneum & Adult & Mouse & $\begin{array}{l}\text { Human follicular fluid } \\
\text { Human cumulus-conditioned medium }\end{array}$ & [116] \\
\hline Skin & Adult & Pig & Follicular fluid & [117] \\
\hline Umbilical cord & Fetal & Goat & Follicular fluid & [118] \\
\hline Umbilical cord & Fetal & Human & Follicular fluid & [119] \\
\hline Wharton's jelly & Fetal & Human & $\begin{array}{l}\text { Follicular fluid } \\
\text { Cumulus cell-conditioned medium }\end{array}$ & [120] \\
\hline
\end{tabular}


Table 3 Azoospermia treated with mesenchymal stromal/stem cells in in vivo model studies

\begin{tabular}{|c|c|c|c|c|c|c|}
\hline Source & Transplantation & Donor species & Therapeutics & Recipient species & Modeling & References \\
\hline Adipose tissue & Allotransplant & Hamster & Cell & Hamster & Busulfan & [121] \\
\hline Adipose tissue & Allotransplant & Mouse & $\begin{array}{l}\text { Cell } \\
\text { Exosome }\end{array}$ & Mouse & Busulfan & [122] \\
\hline Adipose tissue & Allotransplant & Rat & Cell & Rat & Busulfan & {$[70,123,124]$} \\
\hline Adipose tissue & Allotransplant & Rat & Cell & Rat & Cisplatin & [125] \\
\hline Adipose tissue & Xenotransplant & Human & Cell & Rat & Torsion & [126] \\
\hline Amnion & Allotransplant & Mouse & Cell & Mouse & Busulfan & [127] \\
\hline Bone marrow & Allotransplant & Guinea pig & Cell & Guinea pig & Busulfan & [128] \\
\hline Bone marrow & Allotransplant & Hamster & Cell & Hamster & Busulfan & [129] \\
\hline Bone marrow & Allotransplant & Mouse & Cell & Mouse & Busulfan & {$[130,131]$} \\
\hline Bone marrow & Allotransplant & Mouse & $\begin{array}{l}\text { Cell } \\
\text { Exosome }\end{array}$ & Mouse & Busulfan & [122] \\
\hline Bone marrow & Allotransplant & Mouse & Cell & Mouse & Cisplatin & [132] \\
\hline Bone marrow & Allotransplant & Rat & Cell & Rat & Busulfan & {$[87,89,133-138]$} \\
\hline Bone marrow & Allotransplant & Rat & Cell & Rat & Doxorubicin & [139] \\
\hline Bone marrow & Allotransplant & Rat & Cell & Rat & Lead nitrate & [140] \\
\hline Bone marrow & Allotransplant & Rat & Cell & Rat & Torsion & [141] \\
\hline Bone marrow & Xenotransplant & Goat & Cell & Mouse & Busulfan & [142] \\
\hline Umbilical cord & Xenotransplant & Human & Cell & Mouse & Busulfan & [143-145] \\
\hline Urine & Allotransplant & Mouse & $\begin{array}{l}\text { Cell } \\
\text { Exosome }\end{array}$ & Mouse & Busulfan & [146] \\
\hline
\end{tabular}

to Matsumoto et al. [52], in the case of applying this type of surgical intervention, stem cells should be processed no later than 1 day after the extraction of the fat material from the body, since storage of the fatty substrate at a room temperature decreases number of viable stem cells. Small portions of autologous adipose tissue extracted from the patient's body with a syringe are easily processed for MSC isolation, whereas the processing of large volume of aspirated fat is associated with certain difficulties [53].

With classical LS, the aspirate is separated into 3 layers: top fatty layer contains homogenized mature adipocytes destroyed during the operation; the middle layer is intact adipose tissue and the bottom layer contains residuals of the solution infiltrated into the patient's tissue before surgery with plasma and blood cells [54]. Both top and bottom layers are removed from the container before processing aspirated fat [54]. The remaining middle layer is washed in sterile phosphate buffer containing antibacterial and antimycotic agents to avoid microbial contamination of the material [54]. Next, the adipose tissue is lysed in sterile collagenase solution to release the components of the SSF containing stem cells [55]. Different types of enzyme are used, but collagenase type IA is the most effective for MSC isolation [56]. Currently, considering the side effects of enzymatic approaches on the MSCs, non-enzymatic explant at isolation methods has been developed [57].
Despite large numbers of registered preclinical and clinical studies, safety of MSC-related therapies has remained the major concern for clinicians. The main risks of MSCs are proinflammatory properties, tumorigenicity, and fibrosis [58]. Among them, tumorigenicity is the most serious and many studies have shown that MSCs have the ability to converse into tumors as well as the ability to trigger tumor development [59]. The excessive productions of cytokines by MSC, such as growth factors and chemokines, directly act on surface receptors of cancer cells, thereby regulating tumor enhancement [60].

\section{MSC therapy of azoospermia from bench to bed}

MSC transplantation is a relatively new therapy proposed to induce spermatogenesis and treat male infertility [61]. Since MSC are involved in processes such as cell survival, proliferation, migration, angiogenesis, and immune modulation, these cells are considered as an ideal material for azoospermia treatment. Achieving this therapeutic method for treatment of NOA using MSC needs evaluation of in vitro and in vivo studies as well as possibility of clinical trials with this purpose.

\section{In vitro studies on MSC and spermatogenesis}

Some studies have indicated that embryonic stem cells very similar to MSCs found in the testes [62]. These cells are located in the basal layer of the testicular 
seminiferous tubules, and they can divide asymmetrically and give rise to progenitor cells. These cells survive chemotherapy and can trigger germinative cell differentiation [63]. They, therefore, serve as a reserve storage for stem cell population [64]. It is likely that the interaction between these cells and the transplanted MSC plays a crucial role in the fertility restoration.

A certain combination of growth factors, chemical components, genetic manipulations, and/or co-culture with other cells can be used to induce the differentiation of MSCs into the male (Table 1) or female germ cell epithelium (Table 2). For differentiation of various types of MSCs into male germ cells, different types of differentiation induction method have been developed as follows: (1) retinoic acid, (2) growth factors, (3) minerals, (4) coculture, (5) conditioned media, (6) magnetic field, and (7) gene over-expression (Table 1). The results of in vitro studies have been published demonstrating that NOA can be restored through MSC transplantation. Furthermore, differentiation of AT-MSCs into male germ cells suggests that cell therapy can help reverse pathological changes in the testicular seminiferous tubules.

\section{MSC therapy in animal model of azoospermia}

MSCs transplanted into the testes of chemical or surgical NOA animal models showed both induction of spermatogenesis and/or differentiation of MSCs into germ cells (Table 3). MSC transplantation improved the expression of germ cell markers in the testes and can be proposed as a suitable method for the treatment of infertility. Several possible mechanisms of testicular function restoration during $\mathrm{MSC}$-induced tissue regeneration have been shown: (1) MSCs may be involved in the suppression of antisperm antibodies (ASA) [147]; (2) MSCs can reduce factors that lead to infertility through reduction of apoptosis [127]; (3) MSCs can reduce oxidative

Table 4 Clinical trials on mesenchymal stromal/stem cells-based therapy for female and male reproductive diseases (U. S. National Library of Medicine)

\begin{tabular}{|c|c|c|c|c|c|c|c|c|}
\hline Sex & Disease/syndrome & Phase & Date & Country & Source & Transplantation & Stage & CT code \\
\hline Female & Atrophic endometrium & 2 & 2019 & Russia & Bone marrow & Autotransplant & Completed & NCT03166189 \\
\hline Female & Fistula vagina & 1 & 2020 & United States & ND & Autotransplant & Completed & NCT03220243 \\
\hline Female & $\begin{array}{l}\text { Intrauterine adhesions } \\
\text { Endometrial dysplasia }\end{array}$ & 4 & 2014 & China & Bone marrow & Autotransplant & ND & NCT02204358 \\
\hline Female & Intrauterine adhesions & ND & 2014 & China & Umbilical cord & Allotransplant & Completed & NCT02313415 \\
\hline Female & Intraventricular hemorrhage & 2 & 2017 & Korea & Umbilical cord & Allotransplant & Recruiting & NCT02890953 \\
\hline Female & Ovarian cancer & 1 & 2019 & United States & ND & Autotransplant & Completed & NCT02530047 \\
\hline Female & Ovarian disease & $1 \& 2$ & 2015 & Jordan & Bone marrow & Autotransplant & Active & NCT03069209 \\
\hline Female & Premature ovarian failure & $1 \& 2$ & 2018 & China & Umbilical cord & Allotransplant & Completed & NCT02644447 \\
\hline Female & Premature ovarian failure & $1 \& 2$ & 2014 & Egypt & Bone marrow & Autotransplant & ND & NCT02696889 \\
\hline Female & Premature ovarian failure & ND & 2016 & United States & Bone marrow & Autotransplant & Active & NCT02696889 \\
\hline Female & Thin endometrium & 1 & 2018 & China & Umbilical cord & Allotransplant & Recruiting & NCT03592849 \\
\hline Female & Thin endometrium & 1 & 2020 & Indonesia & Endometrium & Autotransplant & Recruiting & NCT04676269 \\
\hline Female & Uterine scar & 2 & 2020 & China & Umbilical cord & Allotransplant & Recruiting & NCT02968459 \\
\hline Female & Uterine scar & 1 & 2020 & China & Umbilical cord & Allotransplant & Recruiting & NCT03181087 \\
\hline Female & Uterus injury & 2 & 2020 & China & Umbilical cord & Allotransplant & Recruiting & NCT03386708 \\
\hline Male & Azoospermia & ND & 2015 & Egypt & Bone marrow & Autotransplant & Completed & NCT02414295 \\
\hline Male & Azoospermia & $1 \& 2$ & 2014 & Egypt & Bone marrow & Autotransplant & ND & NCT02025270 \\
\hline Male & Azoospermia & ND & 2013 & Egypt & Bone marrow & Autotransplant & Recruiting & NCT02008799 \\
\hline Male & Azoospermia & $1 \& 2$ & 2014 & Egypt & Bone marrow & Autotransplant & Recruiting & NCT02041910 \\
\hline Male & Azoospermia & $1 \& 2$ & 2015 & Jordan & Bone marrow & Autotransplant & Recruiting & NCT02641769 \\
\hline Male & $\begin{array}{l}\text { Azoospermia } \\
\text { Oligospermia }\end{array}$ & 2 & 2018 & Russia & Adipose tissue & Autotransplant & Recruiting & NCT03762967 \\
\hline Male & Erectile dysfunction & 1 & 2018 & Jordan & Wharton's Jelly & Allotransplant & Completed & NCT02945449 \\
\hline Male & Erectile dysfunction & $1 \& 2$ & 2019 & Jordan & Wharton's Jelly & Allotransplant & Completed & NCT03751735 \\
\hline Male & Erectile dysfunction & 1 & 2018 & Korea & Bone marrow & Autotransplant & Completed & NCT02344849 \\
\hline Male & Erectile dysfunction & 2 & 2020 & Korea & Bone marrow & Autotransplant & Recruiting & NCT04594850 \\
\hline
\end{tabular}


stress [139]; (4) MSCs can stimulate testosterone production [126] with differentiation into Laydig cells [148]; (5) MSCs can differentiate into target cells [133]; (6) the transplanted cells secrete growth factors such as bone morphogenetic proteins (BMPs) and transforming growth factor beta (TGF- $\beta$ ), which are male germ cell inducing factors with ability to stimulate restoration of the recipient's cellular function [149]; (7) MSCs connect with endogenous cells, restoring the function of damaged cells [150]; (8) MSCs reverse the glycolysis and glycogenesis imbalance in sperm by regulating Akt/ glycogen synthase kinase 3 (GSK3) axis [151]; and (9) MSCs can alter expression of some spermatogenesisrelated miRNAs and their target genes [134].

\section{MSC therapy of azoospermia patients}

Studies on in vitro differentiation of MSCs to germ cells and MSC therapy of animal models of azoospermia have showed the possibility of using MSC therapy to treat azoospermia in humans. Various clinical trials for the treatment of infertility in reproductive diseases in both women and men have been recorded or completed (Table 4). However, no studies have been published to treat azoospermia with the help of MSCs except an abstract from Jordan scientists demonstrating therapeutic effects of intratesticular injections of CD34/CD133 BMMSCs in azoospermia men. At the same time, based on the information available in the US National Library of Medicine and in the Iranian Registry of Clinical Trials, 6 studies (Table 4) and 1 study (IRCT20190519043634N1), respectively, have been recruited for this purpose.

\section{Conclusions}

The potential of MSCs in restoration of fertility in patients with NOA has been shown in this systematic review. Mastering and successfully applying this technique in clinical practice can help a vast group of patients to revive spermatogenesis and enjoy fatherhood. Based on the current knowledge answering to this important question "which MSCs source have a better therapeutic potential to azoospermia?" is not easy. Lack of comparing studies between the MSCs' sources for treatment of azoospermia in the three layers of in vitro and in vivo studies and clinical trials made it difficult to rank the cell sources. By the way, considering the efficiency of cell isolation and complications of achieving a good cell source including higher number of cell yield, lower surgical manipulations, and similarity of donor cells and recipient, we can suggest adipose tissue-derived MSCs for treatment of azoospermia. However, other MSC sources may also be efficient for cell therapy of azoospermia.

\section{Abbreviations}

ASA: Antisperm antibodies; AT-MSC: Adipose tissue-derived mesenchymal stromal/stem cell; BM-MSC: Bone marrow-derived mesenchymal stromal/ stem cell; BMP: Bone morphogenetic protein; FSH: Follicle-stimulating hormone; GSK3: Glycogen synthase kinase 3; ICSI: Intracytoplasmic sperm injection; IVF: In vitro fertilization; LH: Luteinizing hormone; LS: Liposuction; MSC: Mesenchymal stromal/stem cell; NOA: Non-obstructive azoospermia; SHBG: Sex hormone-binding globulin; SSF: Stromal-vascular fraction; TESE: Testicular sperm extraction; TGF- $\beta$ : Transforming growth factor beta; WHO: World Health Organization

\section{Acknowledgments}

Not applicable.

\section{Authors' contributions}

U.Z., R.S., I.N., and A.T. conceived and designed the format of the manuscript. R.Z., N.B., M.A., D.S., A.I., B.K., and A.K. drafted and edited the manuscript. U.Z., R.S., I.N., and A.T. reviewed the manuscript. All authors contributed to the critical reading and discussion of the manuscript. The authors have read and agreed to the published version of the final manuscript. All authors read and approved the final manuscript.

\section{Funding}

This study has been financially supported by Allame Tabatabaei Post-Doc Fellowship Program from Iran's National Elites Foundation (INEF). The funder had no role in study design, data collection and analysis, decision to publish, or preparation of the manuscript.

Availability of data and materials

Not applicable.

\section{Declarations}

Ethics approval and consent to participate

Not applicable.

\section{Consent for publication}

Not applicable.

\section{Competing interests}

The authors declare that they have no competing interests.

Received: 22 January 2021 Accepted: 17 March 2021

Published online: 06 April 2021

\section{References}

1. Thompson M, Mei SH, Wolfe D, Champagne J, Fergusson D, Stewart DJ, et al. Cell therapy with intravascular administration of mesenchymal stromal cells continues to appear safe: an updated systematic review and meta-analysis. EClinicalMedicine. 2020;19:100249. https://doi.org/10.1016/j.eclinm.2019.100249.

2. Kim HJ, Park J-S. Usage of human mesenchymal stem cells in cell-based therapy: advantages and disadvantages. Dev Reprod. 2017;21(1):1-10. https://doi.org/10.12717/DR.2017.21.1.001.

3. Organization $\mathrm{WH}$. Revised glossary on assisted reproductive terminology (ART). Fertil Steril. 2009:92(5):1520-4.

4. Boivin J, Bunting L, Collins JA, Nygren KG. International estimates of infertility prevalence and treatment-seeking: potential need and demand for infertility medical care. Hum Reprod. 2007;22(6):1506-12. https://doi.org/10.1 093/humrep/dem046.

5. Vander Borght M, Wyns C. Fertility and infertility: definition and epidemiology. Clin Biochem. 2018;62:2-10. https://doi.org/10.1016/j. clinbiochem.2018.03.012

6. Katz DJ, Teloken P, Shoshany O. Male infertility-the other side of the equation. Aust Fam Physician. 2017;46(9):641.

7. Duca Y, Calogero AE, Cannarella R, Condorelli RA, La Vignera S. Current and emerging medical therapeutic agents for idiopathic male infertility. Expert Opin Pharmacother. 2019:20(1):55-67. https://doi.org/10.1080/14656566.2018.1543405.

8. Wosnitzer M, Goldstein M, Hardy MP. Review of azoospermia. Spermatogenesis. 2014;4:e28218-e.

9. Oud MS, Ramos L, O'Bryan MK, McLachlan Rl, Okutman Ö, Viville S, et al. Validation and application of a novel integrated genetic screening method to a cohort of 1,112 men with idiopathic azoospermia or severe oligozoospermia. Hum Mutat. 2017;38(11):1592-605. https://doi.org/10.1002/ humu.23312. 
10. Kumanov P. Managing infertility due to endocrine causes. In: The Diagnosis and Treatment of Male Infertility, Aziz N, Agarwal A. (Eds): Springer, Switzerland; 2017. p. 63-78.

11. Gordetsky J, van Wijngaarden E, O'Brien J. Redefining abnormal folliclestimulating hormone in the male infertility population. BJU Int. 2012;110(4): 568-72. https://doi.org/10.1111/j.1464-410X.2011.10783.x.

12. Ring J, Welliver C, Parenteau M, Markwell S, Brannigan RE, Köhler TS. The utility of sex hormone-binding globulin in hypogonadism and infertile males. J Urol. 2017;197(5):1326-31. https://doi.org/10.1016/j.juro.2017.01.018.

13. Fernandez CJ, Chacko EC, Pappachan JM. Male obesity-related secondary hypogonadism-pathophysiology. Clin Implications Manage Eur Endocrinol. 2019;15(2):83.

14. Hammond GL. Sex hormone-binding globulin and the metabolic syndrome. In: Male Hypogonadism, Winters S, Huhtaniemi IT (Eds.): Springer, Switzerland; 2017. p. 305-324.

15. Medicine PCotASfR. Management of nonobstructive azoospermia: a committee opinion. Fertil Steril. 2018;110(7):1239-45. https://doi.org/10.101 6/j.fertnstert.2018.09.012.

16. Vij SC, Sabanegh E Jr, Agarwal A. Biological therapy for non-obstructive azoospermia. Expert Opin Biol Ther. 2018;18(1):19-23. https://doi.org/10.1 080/14712598.2018.1380622.

17. Caroppo E, Colpi E, Gazzano G, Vaccalluzzo L, Piatti E, D'Amato G, et al. The seminiferous tubule caliber pattern as evaluated at high magnification during microdissection testicular sperm extraction predicts sperm retrieval in patients with non-obstructive azoospermia. Andrology. 2019;7(1):8-14. https://doi.org/10.1111/andr.12548.

18. Ishikawa T. Surgical recovery of sperm in non-obstructive azoospermia Asian J Androl. 2012;14(1):109-15. https://doi.org/10.1038/aja.2011.61.

19. Corona G, Minhas S, Giwercman A, Bettocchi C, Dinkelman-Smit M, Dohle G, Fusco F, Kadioglou A, Kliesch S, Kopa Z, Krausz C, Pelliccione F, Pizzocaro A, Rassweiler J, Verze P, Vignozzi L, Weidner W, Maggi M, Sofikitis N. Sperm recovery and ICSI outcomes in men with non-obstructive azoospermia: a systematic review and meta-analysis. Hum Reprod Update. 2019;25(6):73357. https://doi.org/10.1093/humupd/dmz028.

20. Esteves SC, Ramasamy R, Colpi GM, Carvalho JF, Schlegel PN. Sperm retrieval rates by micro-TESE versus conventional TESE in men with nonobstructive azoospermia - the assumption of independence in effect sizes might lead to misleading conclusions. Hum Reprod Update. 2020;26(4):6035. https://doi.org/10.1093/humupd/dmaa006.

21. Yalcin I, Berker B, Sukur YE, Kahraman K, Ates C. Comparison of intracytoplasmic sperm injection with testicular spermatozoa success in infertile men with obstructive and non-obstructive azoospermia; a retrospective analysis. Hum Fertil. 2017;20(3):186-91. https://doi.org/10.1 080/14647273.2016.1264632.

22. Oses R, Villarroel MZ, Medel P, Ojeda MG, Viola J, Valcarcel A. TESE-ICSI in couples with nonobstructive azoospermia: comparison between fresh or previously cryopreserved testicular sperm. Fertil Steril. 2018;110(4):e289. https://doi.org/10.1016/j.fertnstert.2018.07.817.

23. Afanasyev BV, Elstner E, Zander AR. AJ Friedenstein, founder of the mesenchymal stem cell concept. Cell Ther Transplant. 2009;1(3):35-8.

24. Friedenstein $\mathrm{A}$, Chailakhjan $\mathrm{R}$, Lalykina $\mathrm{K}$. The development of fibroblast colonies in monolayer cultures of Guinea-pig bone marrow and spleen cells. Cell Prolif. 1970;3(4):393-403. https://doi.org/10.1111/j.1365-2184.1970. tb00347.x

25. Andrzejewska A, Lukomska B, Janowski M. Concise review: mesenchymal stem cells: from roots to boost. Stem Cells. 2019;37(7):855-64. https://doi. org/10.1002/stem.3016

26. Scadden DT. The stem-cell niche as an entity of action. Nature. 2006; 441(7097):1075-9. https://doi.org/10.1038/nature04957.

27. Manaph NPA, Sivanathan KN, Nitschke J, Zhou X-F, Coates PT, Drogemuller CJ. An overview on small molecule-induced differentiation of mesenchymal stem cells into beta cells for diabetic therapy. Stem Cell Res Ther. 2019; 10(1):293.

28. Ibrahim A, Marbán E. Exosomes: fundamental biology and roles in cardiovascular physiology. Annu Rev Physiol. 2016;78(1):67-83. https://doi. org/10.1146/annurev-physiol-021115-104929.

29. Jiang $N$, Xiang L, He L, Yang G, Zheng J, Wang C, Zhang Y, Wang S, Zhou Y, Sheu TJ, Wu J, Chen K, Coelho PG, Tovar NM, Kim SH, Chen M, Zhou YH, Mao JJ. Exosomes mediate epithelium-mesenchyme crosstalk in organ development. ACS Nano. 2017;11(8):7736-46. https://doi.org/10.1021/acsna no.7b01087.
30. Yeung CLA, Co N-N, Tsuruga T, Yeung T-L, Kwan S-Y, Leung CS, et al. Exosomal transfer of stroma-derived miR21 confers paclitaxel resistance in ovarian cancer cells through targeting APAF1. Nat Commun. 2016;7(1):1-14.

31. Basu J, Ludlow JW. Exosomes for repair, regeneration and rejuvenation. Expert Opin Biol Ther. 2016;16(4):489-506. https://doi.org/10.1517/14712 598.2016 .1131976

32. Kingery MT, Manjunath AK, Anil U, Strauss EJ. Bone marrow mesenchymal stem cell therapy and related bone marrow-derived orthobiologic therapeutics. Curr Rev Musculoskelet Med. 2019;12(4):451-9. https://doi. org/10.1007/s12178-019-09583-1.

33. Ganguly P, El-Jawhari JJ, Giannoudis PV, Burska AN, Ponchel F, Jones EA Age-related changes in bone marrow mesenchymal stromal cells: a potential impact on osteoporosis and osteoarthritis development. Cell Transplant. 2017;26(9):1520-9. https://doi.org/10.1177/0963689717721201.

34. Jin HJ, Bae YK, Kim M, Kwon S-J, Jeon HB, Choi SJ, Kim S, Yang Y, Oh W, Chang J. Comparative analysis of human mesenchymal stem cells from bone marrow, adipose tissue, and umbilical cord blood as sources of cell therapy. Int J Mol Sci. 2013;14(9):17986-8001. https://doi.org/10.3390/ijms14 0917986.

35. Choe SS, Huh JY, Hwang IJ, Kim JI, Kim JB. Adipose tissue remodeling: its role in energy metabolism and metabolic disorders. Front Endocrinol (Lausanne). 2016;7:30.

36. Rodbell M. Localization of lipoprotein lipase in fat cells of rat adipose tissue. J Biol Chem. 1964;239(3):753-5. https://doi.org/10.1016/S0021-9258(18)51 653-7.

37. Han S, Sun HM, Hwang K-C, Kim S-W. Adipose-derived stromal vascular fraction cells: update on clinical utility and efficacy. Critical Reviews ${ }^{\mathrm{TM}}$ in Eukaryotic Gene Expression. 2015;25(2):145-152.

38. Zuk PA, Zhu M, Mizuno H, Huang J, Futrell JW, Katz AJ, Benhaim P, Lorenz HP, Hedrick MH. Multilineage cells from human adipose tissue: implications for cell-based therapies. Tissue Eng. 2001;7(2):211-28. https://doi.org/10.1 089/107632701300062859.

39. Uccelli A, Moretta L, Pistoia V. Immunoregulatory function of mesenchymal stem cells. Eur J Immunol. 2006;36(10):2566-73. https://doi.org/10.1002/eji.2 00636416

40. Fraser JK, Zhu M, Wulur I, Alfonso Z. Adipose-derived stem cells. In: Mesenchymal Stem Cells, Prockop DJ, Phinney DG, Bunnell BA (Eds.): Springer, Switzerland; 2008. p. 59-67.

41. Fraser JK. Hedrick MH. Google Patents: Method for processing lipoaspirate cells; 2008.

42. Li Y, Jiang Q-L, Van der Merwe L, Lou D-H, Lin C. Preclinical efficacy of stem cell therapy for skin flap: a systematic review and meta-analysis. Stem Cell Res Ther. 2021;12(1):28.

43. Dubois SG, Floyd EZ, Zvonic S, Kilroy G, Wu X, Carling S, et al. Isolation of human adipose-derived stem cells from biopsies and liposuction specimens. In: Mesenchymal Stem Cells, Prockop DJ, Phinney DG, Bunnell BA (Eds.): Springer, Switzerland; 2008. p. 69-79.

44. Tarallo M, Fino P, Ribuffo D, Casella D, Toscani M, Spalvieri C, Lattanzi W, di Taranto G. Liposuction aspirate fluid adipose-derived stem cell injection and secondary healing in fingertip injury: a pilot study. Plast Reconstr Surg. 2018; 142(1):136-47. https://doi.org/10.1097/PRS.0000000000004506.

45. Chia CT, Neinstein RM, Theodorou SJ. Evidence-based medicine: liposuction. Plast Reconstr Surg. 2017;139(1):267e-74e.

46. Jewell ML. Ultrasonic-assisted liposuction: introduction and historic perspectives. In: Ultrasound-Assisted Liposuction, Garcia JO (Ed.): Springer, Switzerland; 2020. p. 3-8

47. Centurion P, Caballero G, Weiss M. Comment to:"laser-assisted liposuction (LAL) versus traditional liposuction: systematic review". Aesthet Plast Surg. 2019;43(4):1122-3. https://doi.org/10.1007/s00266-018-1110-5.

48. Wollina U, Heinig B. Madelung's disease-case series and treatment by tumescent liposuction or lipectomy. Open Access Macedonian J Med Sci. 2017:5(4):427-31. https://doi.org/10.3889/oamjms.2017.114.

49. Schneider S, Unger M, van Griensven M, Balmayor ER. Adiposederived mesenchymal stem cells from liposuction and resected fat are feasible sources for regenerative medicine. Eur J Med Res. 2017; 22(1):1-11.

50. Grambow F, Rutkowski R, Podmelle F, Schmoeckel K, Siegerist F, Domanski G, Schuster MW, Domanska G. The impact of Lidocaine on adipose-derived stem cells in human adipose tissue harvested by liposuction and used for lipotransfer. Int J Mol Sci. 2020:21(8):2869. https://doi.org/10.3390/ijms21082869. 
51. Keck M, Kober J, Riedl O, Kitzinger HB, Wolf S, Stulnig TM, Zeyda M, Gugerell A. Power assisted liposuction to obtain adipose-derived stem cells: impact on viability and differentiation to adipocytes in comparison to manual aspiration. J Plast Reconstr Aesthet Surg. 2014;67(1):e1-8. https://doi.org/1 0.1016/j.bjps.2013.08.019

52. Matsumoto $D$, Shigeura $T$, Sato $K$, Inoue $K$, Suga $H$, Kato $H$, Aoi $N$, Murase $S$, Gonda K, Yoshimura K. Influences of preservation at various temperatures on liposuction aspirates. Plast Reconstr Surg. 2007;120(6):1510-7. https://doi. org/10.1097/01.prs.0000288015.70922.e4.

53. Schreml S, Babilas P, Fruth S, Orsó E, Schmitz G, Mueller MB, Nerlich M, Prantl L. Harvesting human adipose tissue-derived adult stem cells: resection versus liposuction. Cytotherapy. 2009;11(7):947-57. https://doi. org/10.3109/14653240903204322.

54. Palumbo P, Miconi G, Cinque B, la Torre C, Lombardi F, Zoccali G, Orsini G, Leocata P, Giuliani M, Cifone MG. In vitro evaluation of different methods of handling human liposuction aspirate and their effect on adipocytes and adipose derived stem cells. J Cell Physiol. 2015;230(8):1974-81. https://doi. org/10.1002/jcp.24965.

55. Mushahary D, Spittler A, Kasper C, Weber V, Charwat V. Isolation, cultivation, and characterization of human mesenchymal stem cells. Cytometry Part A. 2018:93(1):19-31. https://doi.org/10.1002/cyto.a.23242.

56. Alstrup T, Eijken M, Bohn AB, Møller B, Damsgaard TE. Isolation of adipose tissue-derived stem cells: enzymatic digestion in combination with mechanical distortion to increase adipose tissue-derived stem cell yield from human aspirated fat. Curr Protoc Stem Cell Biol. 2019;48(1):e68. https:// doi.org/10.1002/cpsc.68.

57. Bellei B, Migliano E, Tedesco M, Caputo S, Picardo M. Maximizing nonenzymatic methods for harvesting adipose-derived stem from lipoaspirate: technical considerations and clinical implications for regenerative surgery. Sci Rep. 2017;7(1):1-15.

58. Han Y, Li X, Zhang Y, Han Y, Chang F, Ding J. Mesenchymal stem cells for regenerative medicine. Cells. 2019;8(8):886. https://doi.org/10.3390/ cells8080886.

59. Li C, Zhao H, Wang B. Mesenchymal stem/stromal cells: developmental origin, tumorigenesis and translational cancer therapeutics. Transl Oncol. 2020;14(1):100948.

60. Melzer C, Yang Y, Hass R. Interaction of MSC with tumor cells. Cell Communication and Signaling. 2016;14(1):20. https://doi.org/10.1186/s12 964-016-0143-0

61. Tamadon A, Zhan-byrbekuly U, Kairgaliyev I, Khoradmehr A. Mesenchymal stem cell therapy of male infertility; Male Reproductive Health: IntechOpen 2019.

62. Chikhovskaya J, Jonker M, Meissner A, Breit T, Repping S, Van Pelt A. Human testis-derived embryonic stem cell-like cells are not pluripotent, but possess potential of mesenchymal progenitors. Hum Reprod. 2012;27(1):210-21. https://doi.org/10.1093/humrep/der383.

63. Bhartiya D. The need to revisit the definition of mesenchymal and adult stem cells based on their functional attributes. Stem Cell Res Ther. 2018;9(1):78.

64. Bhartiya D, Anand S. Effects of oncotherapy on testicular stem cells and niche. MHR. 2017;23(9):654-5.

65. Wei Y, Fang J, Cai S, Lv C, Zhang S, Hua J. Primordial germ cell-like cells derived from canine adipose mesenchymal stem cells. Cell Prolif. 2016;49(4): 503-11. https://doi.org/10.1111/cpr.12271.

66. Fang J, Wei Y, Lv C, Peng S, Zhao S, Hua J. CD61 promotes the differentiation of canine ADMSCs into PGC-like cells through modulation of TGF- $\beta$ signaling. Sci Rep. 2017;7(1):43851. https://doi.org/10.1038/srep43851.

67. P-z L, G-y Y, Han L, Pang J, B-s Z, G-m Z, et al. Overexpression of STRA8, BOULE, and DAZL genes promotes goat bone marrow-derived mesenchymal stem cells in vitro transdifferentiation toward putative male germ cells. Reprod Sci. 2017;24(2):300-12.

68. Liu H, Chen M, Liu L, Ren S, Cheng P, Zhang H. Induction of human adiposederived mesenchymal stem cells into germ lineage using retinoic acid. Cellular Reprogramming. 2018;20(2):127-34. https://doi.org/10.1089/cell.2017.0063.

69. Ghatreh K, Eliyasi M, Alaei S, Saki G. Differentiation potential of adipose tissue-derived mesenchymal stem cells into germ cells with and without growth factors. Andrologia. 2021;53(1):e13892.

70. Luo Y, Xie L, Mohsin A, Ahmed W, Xu C, Peng Y, Hang H, Zhuang Y, Chu J, Guo M. Efficient generation of male germ-like cells derived during coculturing of adipose-derived mesenchymal stem cells with Sertoli cells under retinoic acid and testosterone induction. Stem Cell Res Ther. 2019; 10(1):91. https://doi.org/10.1186/s13287-019-1181-5.
71. Bräunig P, Glanzner W, Rissi V, Gonçalves P. The differentiation potential of adipose tissue-derived mesenchymal stem cells into cell lineage related to male germ cells. Arquivo Brasileiro de Medicina Veterinária e Zootecnia. 2018;70(1):160-8. https://doi.org/10.1590/1678-4162-9132.

72. Alifi F, Asgari HR. Alteration in expression of primordial germ cell (PGC) markers during induction of human amniotic mesenchymal stem cells (hAMSCs). J Reprod Infertil. 2020;21(1):59.

73. Afsartala Z, Rezvanfar MA, Hodjat M, Tanha S, Assadollahi V, Bijangi K, Abdollahi M, Ghasemzadeh-Hasankolaei M. Amniotic membrane mesenchymal stem cells can differentiate into germ cells in vitro. In Vitro Cell Dev Biol Anim. 2016;52(10):1060-71. https://doi.org/10.1007/s11626-01 6-0073-6.

74. Yan G, Fan Y, Li P, Zhang Y, Wang F. Ectopic expression of DAZL gene in goat bone marrow-derived mesenchymal stem cells enhances the transdifferentiation to putative germ cells compared to the exogenous treatment of retinoic acid or bone morphogenetic protein 4 signalling molecules. Cell Biol Int. 2015;39(1):74-83. https://doi.org/10.1002/cbin.10348.

75. Salem M, Mirzapour T, Bayrami A, Sagha M. Germ cell differentiation of bone marrow mesenchymal stem cells. Andrologia. 2019;51(4):e13229. https://doi.org/10.1111/and.13229.

76. Drusenheimer N, Wulf G, Nolte J, Lee JH, Dev A, Dressel R, et al. Putative human male germ cells from bone marrow stem cells. Soc Reprod Fertil Suppl. 2007;63:69.

77. Mazaheri Z, Movahedin M, Rahbarizadeh F, Amanpour S. Different doses of bone morphogenetic protein 4 promote the expression of early germ cellspecific gene in bone marrow mesenchymal stem cells. In Vitro Cell Dev Biol Anim. 2011;47(8):521-5. https://doi.org/10.1007/s11626-011-9429-0.

78. Shirazi R, Zarnani AH, Soleimani M, Abdolvahabi MA, Nayernia K, Kashani IR. BMP4 can generate primordial germ cells from bone-marrow-derived pluripotent stem cells. Cell Biol Int. 2012;36(12):1185-93. https://doi.org/10.1 042/CBI20110651.

79. Shirzeyli MH, Khanlarkhani N, Amidi F, Shirzeyli FH, Aval FS, Sobhani A Bones Morphogenic Protein-4 and retinoic acid combined treatment comparative analysis for in vitro differentiation potential of murine mesenchymal stem cells derived from bone marrow and adipose tissue into germ cells. Microsc Res Tech. 2017;80(11):1151-60. https://doi.org/10.1002/ jemt.22880.

80. Behzadi Fard S, Mazaheri Z, Ghorbanmehr N, Movahedin M, Behzadi Fard M, Gholampour MA. Analysis of MiRNA-17 and MiRNA-146 expression during differentiation of spermatogonial stem like cells derived from mouse bone marrow mesenchymal stem cells. Int J Mol Cell Med. 2019;8(1):14-23.

81. Nayernia K, Lee JH, Drusenheimer N, Nolte J, Wulf G, Dressel R, Gromoll J, Engel W. Derivation of male germ cells from bone marrow stem cells. Lab Investig. 2006;86(7):654-63. https://doi.org/10.1038/labinvest.3700429.

82. Shirazi R, Zarnani AH, Soleimani M, Nayernia K, Ragerdi Kl. Differentiation of bone marrow-derived stage-specific embryonic antigen 1 positive pluripotent stem cells into male germ cells. Microsc Res Tech. 2017;80(4): 430-40. https://doi.org/10.1002/jemt.22812.

83. Kashani IR, Zarnani AH, Soleimani M, Abdolvahabi MA, Nayernia K, Shirazi R. Retinoic acid induces mouse bone marrow-derived CD15+, Oct4+ and CXCR4+ stem cells into male germ-like cells in a two-dimensional cell culture system. Cell Biol Int. 2014;38(6):782-9. https://doi.org/10.1002/cbin.10260.

84. Monfared MH, Minaee B, Rastegar T, Khrazinejad E, Barbarestani M. Sertoli cell condition medium can induce germ like cells from bone marrow derived mesenchymal stem cells. Iran J Basic Med Sci. 2016;19(11):1186-92.

85. Jouni FJ, Abdolmaleki P, Behmanesh M, Movahedin M. An in vitro study of the impact of $4 \mathrm{mT}$ static magnetic field to modify the differentiation rate of rat bone marrow stem cells into primordial germ cells. Differentiation. 2014; 87(5):230-7. https://doi.org/10.1016/j.diff.2014.06.001.

86. Ghorbanlou M, Abdanipour A, Shirazi R, Malekmohammadi N, Shokri S, Nejatbakhsh R. Indirect co-culture of testicular cells with bone marrow mesenchymal stem cells leads to male germ cell-specific gene expressions. Cell J. 2019;20(4):505-12

87. Aziz MTA, Mostafa T, Atta H, Asaad S, Fouad HH, Mohsen G, et al. In vitro and in vivo lineage conversion of bone marrow stem cells into germ cells in experimental azoospermia in rat. Stem Cell Stud. 2011;1(1):e15-e.

88. Kumar K, Das K, Madhusoodan A, Kumar A, Singh P, Mondal T, et al. Rat bone marrow derived mesenchymal stem cells differentiate to germ cell like cells. bioRxiv. 2018:418962. https://doi.org/10.1101/418962

89. Zhang D, Liu X, Peng J, He D, Lin T, Zhu J, Li X, Zhang Y, Wei G. Potential spermatogenesis recovery with bone marrow mesenchymal stem cells in an 
azoospermic rat model. Int J Mol Sci. 2014;15(8):13151-65. https://doi.org/1 0.3390/ijms150813151.

90. Ghasemzadeh-Hasankolai M, Batavani R, Eslaminejad MB, Sedighi-Gilani M. Effect of zinc ions on differentiation of bone marrow-derived mesenchymal stem cells to male germ cells and some germ cell-specific gene expression in rams. Biol Trace Elem Res. 2012;150(1-3):137-46. https://doi.org/10.1007/ s12011-012-9484-8.

91. Ghasemzadeh-Hasankolaei M, Sayahpour FA, Ghasemzadeh-Hasankolaei M, Ghorbanian MT, Eslaminejad MB. Organic and inorganic zinc show similar regulatory effects on the expression of some germ cell specific markers induced in bone marrow mesenchymal stem cells after treatment with retinoic acid. Biologia. 2019;74(12):1721-31. https://doi.org/10.2478/s11756019-00306-y.

92. Ghasemzadeh-Hasankolaei M, Eslaminejad MB, Sedighi-Gilani M. Derivation of male germ cells from ram bone marrow mesenchymal stem cells by three different methods and evaluation of their fate after transplantation into the testis. In Vitro Cell Dev Biol Anim. 2016;52(1):49-61. https://doi. org/10.1007/s11626-015-9945-4.

93. Ghasemzadeh-Hasankolaei M, Eslaminejad MB, Batavani R, Sedighi-Gilani M. Comparison of the efficacy of three concentrations of retinoic acid for transdifferentiation induction in sheep marrow-derived mesenchymal stem cells into male germ cells. Andrologia. 2014;46(1):24-35. https://doi.org/1 0.1111 /and.12037.

94. Ghasemzadeh-Hasankolaei M, Sedighi-Gilani M, Eslaminejad M. Induction of ram bone marrow mesenchymal stem cells into germ cell lineage using transforming growth factor- $\beta$ superfamily growth factors. Reprod Domest Anim. 2014;49(4):588-98. https://doi.org/10.1111/rda.12327.

95. Hua J, Pan S, Yang C, Dong W, Dou Z, Sidhu KS. Derivation of male germ cell-like lineage from human fetal bone marrow stem cells. Reprod BioMed Online. 2009;19(1):99-105. https://doi.org/10.1016/S1472-6483(10)60052-1.

96. Hua J, Yu H, Dong W, Yang C, Gao Z, Lei A, Sun Y, Pan S, Wu Y, Dou Z. Characterization of mesenchymal stem cells (MSCs) from human fetal lung: potential differentiation of germ cells. Tissue Cell. 2009;41(6):448-55. https:// doi.org/10.1016/j.tice.2009.05.004.

97. Hua J, Qiu P, Zhu H, Cao H, Wang F, Li W. Multipotent mesenchymal stem cells (MSCs) from human umbilical cord: potential differentiation of germ cells. Afr J Biochem Res. 2011;5(4):113-23.

98. Latifpour M, Shakiba Y, Amidi F, Mazaheri Z, Sobhani A. Differentiation of human umbilical cord matrix-derived mesenchymal stem cells into germlike cells. Avicenna J Med Biotechnol. 2014;6(4):218

99. Li N, Pan S, Zhu H, Mu H, Liu W, Hua J. BMP4 promotes SSEA-1+ hUC-MSC differentiation into male germ-like cells in vitro. Cell Prolif. 2014;47(4):299309. https://doi.org/10.1111/cpr.12115.

100. Li B, Liu W, Zhuang M, Li N, Wu S, Pan S, Hua J. Overexpression of CD61 promotes hUC-MSC differentiation into male germ-like cells. Cell Prolif. 2016;49(1):36-47. https://doi.org/10.1111/cpr.12236.

101. Majidi F, Bamehr H, Shalchian Z, Kouchakian MR, Mohammadzadeh N, Khalili A. Differentiation of human umbilical cord mesenchymal stem cell into germ-like cell under effect of co-culture with testicular cell tissue. Anat Histol Embryol. 2020;49(3):359-64. https://doi.org/10.1111/ahe.12537.

102. Amidi F, Ataie Nejad N, Agha Hoseini M, Nayernia K, Mazaheri Z, Yamini N, Saeednia S. In vitro differentiation process of human Wharton's jelly mesenchymal stem cells to male germ cells in the presence of gonadal and non-gonadal conditioned media with retinoic acid. In Vitro Cell Dev Biol Anim. 2015;51(10):1093-101. https://doi.org/10.1007/s11626-015-9929-4.

103. Ataie Nejad N, Amidi F, Hoseini MA, Nia KN, Habibi M, Kajbafzadeh AM, et al. Male germ-like cell differentiation potential of human umbilical cord Wharton's jelly-derived mesenchymal stem cells in co-culture with human placenta cells in presence of BMP4 and retinoic acid. Iran J Basic Med Sci. 2015;18(4):325-33.

104. Huang $P$, Lin $L M, W u X Y$, Tang $Q L$, Feng $X Y$, Lin GY, et al. Differentiation of human umbilical cord Wharton's jelly-derived mesenchymal stem cells into germ-like cells in vitro. J Cell Biochem. 2010;109(4):747-54.

105. Dissanayake D, Patel H, Wijesinghe P. Differentiation of human male germ cells from Wharton's jelly-derived mesenchymal stem cells. Clin Exp Reprod Med. 2018;45(2):75-81. https://doi.org/10.5653/cerm.2018.45.2.75.

106. Ghaem Maghami R, Mirzapour T, Bayrami A. Differentiation of mesenchymal stem cells to germ-like cells under induction of Sertoli cell-conditioned medium and retinoic acid. Andrologia. 2018;50(3):e12887. https://doi.org/10.1111/and.12887.

107. Xie L, Lin L, Tang Q, Li W, Huang T, Huo X, et al. Sertoli cell-mediated differentiation of male germ cell-like cells from human umbilical cord
Wharton's jelly-derived mesenchymal stem cells in an in vitro co-culture system. Eur J Med Res. 2015;20(1):1-10.

108. Song S-H, Kumar BM, Kang E-J, Lee Y-M, Kim T-H, Ock S-A, Lee SL, Jeon BG, Rho GJ. Characterization of porcine multipotent stem/stromal cells derived from skin, adipose, and ovarian tissues and their differentiation in vitro into putative oocyte-like cells. Stem Cells Dev. 2011;20(8):1359-70. https://doi. org/10.1089/scd.2010.0203

109. Asgari HR, Akbari M, Yazdekhasti H, Rajabi Z, Navid S, Aliakbari F, et al. Comparison of human amniotic, chorionic, and umbilical cord multipotent mesenchymal stem cells regarding their capacity for differentiation toward female germ cells. Cell Reprogram. 2017;19(1):44-53.

110. Taheri Moghadam M, Saki G, Nikbakht R, Eftekhari Moghadam AR. Bone morphogenetic protein 15 induces differentiation of mesenchymal stem cells derived from human follicular fluid to oocyte-like cell. Cell Biol Int. 2021;45(1):127-39. https://doi.org/10.1002/cbin.11475.

111. Eyni H, Ghorbani S, Shirazi R, Salari Asl L, P Beiranvand S, Soleimani M. Three-dimensional wet-electrospun poly (lactic acid)/multi-wall carbon nanotubes scaffold induces differentiation of human menstrual bloodderived stem cells into germ-like cells. J Biomater Appl 2017;32(3):373-383, doi: https://doi.org/10.1177/0885328217723179.

112. Lai $D$, Guo $Y$, Zhang $Q$, Chen $Y$, Xiang C. Differentiation of human menstrual blood-derived endometrial mesenchymal stem cells into oocyte-like cells. Acta Biochim Biophys Sin. 2016;48(11):998-1005. https://doi.org/10.1093/a bbs/gmw090

113. Lv X, Zhu H, Bai Y, Chu Z, Hu Y, Cao H, Liu C, He X, Peng S, Gao Z, Yang C, Hua J. Reversine promotes porcine muscle derived stem cells (PMDSCs) differentiation into female germ-like cells. J Cell Biochem. 2012;113(12): 3629-42. https://doi.org/10.1002/jcb.24296.

114. Lee Y-M, Kim T-H, Lee J-H, Lee W-J, Jeon R-H, Jang S-J, Ock SA, Lee SL, Park BW, Rho GJ. Overexpression of Oct4 in porcine ovarian stem/stromal cells enhances differentiation of oocyte-like cells in vitro and ovarian follicular formation in vivo. Journal of Ovarian Research. 2016;9(1):24. https://doi.org/1 0.1186/s13048-016-0233-z.

115. de Souza G, Costa J, da Cunha E, Passos J, Ribeiro R, Saraiva M, van den Hurk R, Silva JRV. Bovine ovarian stem cells differentiate into germ cells and oocyte-like structures after culture in vitro. Reprod Domest Anim. 2017:52(2): 243-50. https://doi.org/10.1111/rda.12886.

116. Mirzaeian L, Eftekhari-Yazdi P, Esfandiari F, Eivazkhani F, Rezazadeh Valojerdi M, Moini A, Fathi R. Induction of mouse peritoneum mesenchymal stem cells into germ cell-like cells using follicular fluid and cumulus cellsconditioned media. Stem Cells Dev. 2019;28(8):554-64. https://doi.org/10.1 089/scd.2018.0149.

117. Dyce PW, Wen L, Li J. In vitro germline potential of stem cells derived from fetal porcine skin. Nat Cell Biol. 2006;8(4):384-90. https://doi.org/10.1038/ncb1388.

118. Qiu P, Bai Y, Liu C, He X, Cao H, Li M, Zhu H, Hua J. A dose-dependent function of follicular fluid on the proliferation and differentiation of umbilical cord mesenchymal stem cells (MSCs) of goat. Histochem Cell Biol. 2012;138(4):593-603. https://doi.org/10.1007/s00418-012-0975-7.

119. Qiu P, Bai Y, Pan S, Li W, Liu W, Hua J. Gender depended potentiality of differentiation of human umbilical cord mesenchymal stem cells into oocyte-like cells in vitro. Cell Biochem Funct. 2013;31(5):365-73. https://doi. org/10.1002/cbf.2981.

120. Zolfaghar M, Mirzaeian L, Beiki B, Naji T, Moini A, Eftekhari-Yazdi $P$, Akbarinejad V, Vernengo AJ, Fathi R. Wharton's jelly derived mesenchymal stem cells differentiate into oocyte like cells in vitro by follicular fluid and cumulus cells conditioned medium. Heliyon. 2020;6(10):e04992. https://doi. org/10.1016/j.heliyon.2020.e04992.

121. Karimaghai N, Tamadon A, Rahmanifar F, Mehrabani D, Jahromi AR, Zare S, et al. Spermatogenesis after transplantation of adipose tissue-derived mesenchymal stem cells in busulfan-induced azoospermic hamster. Iran J Basic Med Sci. 2018;21(7):660

122. Zhankina R, Afshar A, Farrar Z, Khoradmehr A, Baghban M, Suleiman M, et al. Restoration of spermatogenesis in azoospermic mice by bone marrow mesenchymal stromal/stem cells conditioned medium. 2021.

123. Cakici C, Buyrukcu B, Duruksu G, Haliloglu AH, Aksoy A, Isık A, Uludag O, Ustun $\mathrm{H}$, Subası C, Karaoz E. Recovery of fertility in azoospermia rats after injection of adipose-tissue-derived mesenchymal stem cells: the sperm generation. Biomed Res Int. 2013;2013:1-18. https://doi.org/10.1155/2013/52 9589

124. Mehrabani D, Hassanshahi MA, Tamadon A, Zare S, Keshavarz S, Rahmanifar $F$, et al. Adipose tissue-derived mesenchymal stem cells repair germinal cells 
of seminiferous tubules of busulfan-induced azoospermic rats. J Hum Reprod Sci. 2015;8(2):103.

125. Meligy FY, Abo Elgheed AT, Alghareeb SM. Therapeutic effect of adiposederived mesenchymal stem cells on Cisplatin induced testicular damage in adult male albino rat. Ultrastruct Pathol. 2019;43(1):28-55. https://doi.org/1 0.1080/01913123.2019.1572256.

126. Hsiao C-H, Ji AT-Q, Chang C-C, Cheng C-J, Lee L-M, Ho JH-C. Local injection of mesenchymal stem cells protects testicular torsion-induced germ cell injury. Stem Cell Res Ther. 2015;6(1):113. https://doi.org/10.1186/s13287-0150079-0.

127. Qian C, Meng Q, Lu J, Zhang L, Li H, Huang B. Human amnion mesenchymal stem cells restore spermatogenesis in mice with busulfaninduced testis toxicity by inhibiting apoptosis and oxidative stress. Stem Cell Res Ther 2020;11(1):1-12, doi: https://doi.org/10.1186/s13287-020-01803-7.

128. Hajihoseini M, Vahdati A, Ebrahim Hosseini S, Mehrabani D, Tamadon A Induction of spermatogenesis after stem cell therapy of azoospermic Guinea pigs. Vet Arh. 2017;87(3):333-50.

129. Tamadon A, Mehrabani D, Rahmanifar F, Jahromi AR, Panahi M, Zare S, Khodabandeh Z, Jahromi IR, Tanideh N, Dianatpour M, Ramzi M, KoohiHoseinabadi $\mathrm{O}$. Induction of spermatogenesis by bone marrow-derived mesenchymal stem cells in busulfan-induced azoospermia in hamster. Int J Stem Cells. 2015;8(2):134-45. https://doi.org/10.15283/ijsc.2015.8.2.134.

130. Kadam P, Ntemou E, Baert Y, Van Laere S, Van Saen D, Goossens E. Cotransplantation of mesenchymal stem cells improves spermatogonial stem cell transplantation efficiency in mice. Stem Cell Res Ther. 2018;9(1):317. https://doi.org/10.1186/s13287-018-1065-0.

131. Lue Y, Erkkila K, Liu PY, Ma K, Wang C, Hikim AS, Swerdloff RS. Fate of bone marrow stem cells transplanted into the testis: potential implication for men with testicular failure. Am J Pathol. 2007;170(3):899-908. https://doi.org/1 0.2353/ajpath.2007.060543

132. Sherif IO, Sabry D, Abdel-Aziz A, Sarhan OM. The role of mesenchymal stem cells in chemotherapy-induced gonadotoxicity. Stem Cell Res Ther. 2018; 9(1):196. https://doi.org/10.1186/s13287-018-0946-6.

133. Ghasemzadeh-Hasankolaei M, Batavani R, Eslaminejad MB, Sayahpour F. Transplantation of autologous bone marrow mesenchymal stem cells into the testes of infertile male rats and new germ cell formation. Int J Stem Cells. 2016;9(2):250-63. https://doi.org/10.15283/ijsc16010.

134. Badawy AA, El-Magd MA, AlSadrah SA, Alruwaili MM. Altered expression of some miRNAs and their target genes following mesenchymal stem cell treatment in busulfan-induced azoospermic rats. Gene. 2020;737:144481. https://doi.org/10.1016/j.gene.2020.144481

135. Zahkook S, Atwa A, Shahat M, Mansour AM, Bakry S. Mesenchymal stem cells restore fertility in induced azoospermic rats following chemotherapy administration. J Reprod Infertil. 2014;5(2):50-7.

136. Rahmanifar F, Tamadon A, Mehrabani D, Zare S, Abasi S, Keshavarz S, et al. Histomorphometric evaluation of treatment of rat azoospermic seminiferous tubules by allotransplantation of bone marrow-derived mesenchymal stem cells. Iran J Basic Med Sci. 2016;19(6):653.

137. Zhou X, Ma Y, Wang X, Liu D, Ren Y, Ji X. Bone marrow mesenchymal stem cells to repair the reproductive system of male azoospermia rats. Zhonghua nan ke xue. 2015;21(8):692-7.

138. Monsefi M, Fereydouni B, Rohani L, Talaei T. Mesenchymal stem cells repair germinal cells of seminiferous tubules of sterile rats. Iran J Reprod Med. 2013;11(7):537-44.

139. Abdelaziz MH, Salah El-Din EY, El-Dakdoky MH, Ahmed TA. The impact of mesenchymal stem cells on doxorubicin-induced testicular toxicity and progeny outcome of male prepubertal rats. Birth Defects Res. 2019;111(13): 906-19. https://doi.org/10.1002/bdr2.1535.

140. Hassan Al, Alam SS. Evaluation of mesenchymal stem cells in treatment of infertility in male rats. Stem Cell Res Ther. 2014;5(6):131. https://doi.org/10.11 86/scrt521.

141. Sabbaghi MA, Bahrami AR, Feizzade B, Kalantar SM, Matin MM, Kalantari M, Aflatoonian A, Saeinasab M. Trial evaluation of bone marrow derived mesenchymal stem cells (MSCs) transplantation in revival of spermatogenesis in testicular torsion. Middle East Fertil Soc J. 2012;17(4): 243-9. https://doi.org/10.1016/j.mefs.2012.06.001.

142. Wang F, Liu C, Zhang S-S, Liu W-S, Hua J-I. Transplantation of goat bone marrow mesenchymal stem cells (gMSCs) help restore spermatogenesis in endogenous germ cells-depleted mouse models. J Integr Agric 2013;12(3): 483-494, doi: https://doi.org/10.1016/S2095-3119(13)60249-X.
143. Yang R-F, Liu T-H, Zhao K, Xiong C-L. Enhancement of mouse germ cellassociated genes expression by injection of human umbilical cord mesenchymal stem cells into the testis of chemical-induced azoospermic mice. Asian J Androl. 2014;16(5):698.

144. Abd Allah SH, Pasha HF, Abdelrahman AA, Mazen NF. Molecular effect of human umbilical cord blood CD34-positive and CD34-negative stem cells and their conjugate in azoospermic mice. Mol Cell Biochem. 2017;428(1-2): 179-91. https://doi.org/10.1007/s11010-016-2928-2.

145. Chen H, Tang Q-L, Wu X-Y, Xie L-C, Lin L-M, Ho G-Y, et al. Differentiation of human umbilical cord mesenchymal stem cells into germ-like cells in mouse seminiferous tubules. Mol Med Report. 2015;12(1):819-28. https://doi. org/10.3892/mmr.2015.3528.

146. Deng C, Xie Y, Zhang C, Ouyang B, Chen H, Lv L, Yao J, Liang X, Zhang Y, Sun X, Deng C, Liu G. Urine-derived stem cells facilitate endogenous spermatogenesis restoration of busulfan-induced nonobstructive azoospermic mice by paracrine exosomes. Stem Cells Dev. 2019;28(19): 1322-33. https://doi.org/10.1089/scd.2019.0026.

147. Aghamir SMK, Salavati A, Yousefie R, Tootian Z, Ghazaleh N, Jamali M, Azimi $P$. Does bone marrow-derived mesenchymal stem cell transfusion prevent antisperm antibody production after traumatic testis rupture? Urology. 2014; 84(1):82-6. https://doi.org/10.1016/j.urology.2014.03.009.

148. Xing X, Zhang Z, Zhong L, Ju G, Zou X, Zhu Y, Sun J. Differentiation of human umbilical cord mesenchymal stem cells into steroidogenic cells in vitro. Exp Ther Med. 2016;12(6):3527-34. https://doi.org/10.3892/etm.201 6.3815 .

149. Hofer HR, Tuan RS. Secreted trophic factors of mesenchymal stem cells support neurovascular and musculoskeletal therapies. Stem Cell Res Ther. 2016;7(1):131. https://doi.org/10.1186/s13287-016-0394-0.

150. Kadam P, Ntemou E, Onofre J, Van Saen D, Goossens E. Does cotransplantation of mesenchymal and spermatogonial stem cells improve reproductive efficiency and safety in mice? Stem Cell Res Ther. 2019;10(1): 310. https://doi.org/10.1186/s13287-019-1420-9.

151. Hsiao C-H, Ji AT-Q, Chang C-C, Chien M-H, Lee L-M, Ho JH-C. Mesenchymal stem cells restore the sperm motility from testicular torsion-detorsion injury by regulation of glucose metabolism in sperm. Stem Cell Res Ther. 2019; 10(1):270. https://doi.org/10.1186/s13287-019-1351-5.

\section{Publisher's Note}

Springer Nature remains neutral with regard to jurisdictional claims in published maps and institutional affiliations. 